УДК 339.92:332.1

DOI: https://doi.org/10.37320/2415-3583/20.2

Корнелюк О.А.

кандидат економічних наук, доцент

Волинський національний університет імені Лесі Українки ORCID: https://orcid.org/0000-0001-6620-1073

Матюшок В.В.

магістр

Волинський національний університет імені Лесі Украйнки

\title{
ТРАНСКОРДОННЕ СПІВРОБІТНИЦТВО РЕГІОНІВ УКРАЇНИ В КОНТЕКСТІ РОЗВИТКУ МІЖНАРОДНОЇ ЕКОНОМІЧНОЇ ІНТЕГРАЦЇ̈
}

Участь регіонів України в транскордонному співробітництві сприяє прискоренню євроінтеграційних процесів Украӥни та є ефективним інструментом досягнення Цілей сталого розвитку. Важлива роль у розвитку транскордонного співробітництва належить створенню і реалізаціі програм сусідства. Зокрема, ие стало одним з ефективних способів залучення фінансів СС. Аналіз сочіально-економічного розвитку регіонів України свідчить про недостатне використання ними потенціалу транскордонної співпраці, у зв'язку з чим постає необхідність активізації транскордонного співробітництва. Необхідною умовою досягнення перспектив сталого просторового розвитку регіонів є розроблення ефективної стратегії транскордонного співробітництва. Почирення пандемії також сформувало потребу в удосконаленні існуючого механізму співпраці.

Ключові слова: транскордонне співробітництво, стратегія транскордонного співробітнииттва, євроінтеграчія, активізація транскордонного співробітництва, сочіально-економічний розвиток регіону, транскордонна програма, транскордонний проєкт.

Постановка проблеми. Транскордонне співробітництво має досить тривалу історію, яка доводить доцільність та ефективність використання такої форми взаємодії прикордонних регіонів. Спільні риси історії, культури, необхідність вирішення спільних проблем сприяють зміцненню транскордонних контактів, вирівнюванню рівнів соціально-економічного розвитку, поліпшенню рівня життя і добробуту населення. Транскордонне співробітництво є сприятливим чинником прискорення євроінтеграційних процесів України та забезпечення дотримання Цілей сталого розвитку, визначених на період до 2030 p.

Аналіз останніх досліджень і публікацій. Дослідженням теоретичних і прикладних аспектів розвитку транскордонного співробітництва займалися провідні зарубіжні та вітчизняні вчені, зокрема: П. Бєлєнький, В. Будкін, В. Гоблик, М. Долішній, I. Журба, В. Кравців, М. Лендєл, П. Луцишин, Н. Мікула, О. Мілашовська, Н. Павліха, В. Павлов, С. Писаренко, І. Студеніков,
Р. Федан та ін. Однак динамічний розвиток сучасного світового господарства, поглиблення процесів глобалізації та інтеграції, загострення економічних, політичних та екологічних проблем зумовлюють актуальність подальших досліджень у цьому напрямі з урахуванням сучасних умов.

Мета статті полягає у дослідженні існуючих тенденцій та узагальненні стратегічних напрямів подальшого розвитку транскордонного співробітництва регіонів України в контексті євроінтеграційних орієнтирів та необхідності підвищення рівня соціальноекономічного розвитку нашої держави.

Виклад основного матеріалу. У науковій економічній літературі та нормативноправових актах існують різні визначення поняття транскордонного співробітництва. У 106-й Мадридській конвенції загальних принципів транскордонного співробітництва воно визначено як «будь-які спільні дії, спрямовані на посилення та поглиблення добросусідських відносин між територіальними громадами або органами влади, 
що знаходяться під юрисдикцією двох або декількох договірних сторін, а також на укладення із цією метою будь-яких необхідних угод або досягнення домовленостей». Згідно із Законом України «Про транскордонне співробітництво», це «спільні дії, спрямовані на встановлення і поглиблення економічних, соціальних, науково-технічних, екологічних, культурних та інших відносин між територіальними громадами, їхніми представницькими органами, місцевими органами виконавчої влади України та територіальними громадами, відповідними органами влади інших держав у межах компетенції, визначеної їхнім національним законодавством» [6].

3 огляду на те, що транскордонне співробітництво є одним із засобів реалізації євроінтеграційних орієнтирів України, необхідно вдосконалювати концептуальні засади та механізми активізації транскордонного співробітництва. Активізацією транскордонного співробітництва запропоновано вважати «сукупність засобів та заходів, спрямованих на поглиблення і розширення транскордонних зв'язків через використання різноманітних форм транскордонного співробітництва, а саме: європейські угруповання, об'єднання транскордонного співробітництва, транскордонне партнерство, транскордонні промислові зони, транскордонні промислові парки, транскордонні проєкти, транскордонна торгівля, транскордонні ринки» [6].

Україна бере участь у дев'яти єврорегіонах, однак у чотирьох із них («Дніпро», «Донбас», «Слобожанщина», «Ярославна») транскордонне співробітництво не здійснюється 32014 р. у зв'язку з військовим конфліктом із Російською Федерацією. Чотири єврорегіони розміщені на кордоні з Свропейським Союзом («Буг», «Верхній Прут», «Карпатський», «Нижній Дунай»). Транскордонне співробітництво у формі єврорегіонів здійснюється в Україні з 1993 р. Важливим етапом у розвитку транскордонного співробітництва України стала її учать у програмах сусідства, які реалізовувалися за підтримки ЄС та мали на меті вирішення таких завдань: сприяння економічному та соціальному розвитку прикордонних регіонів, охорона навколишнього середовища, охорона здоров'я, боротьба з організованою злочинністю, розвиток прикордонної інфраструктури та розвиток особистих контактів населення. Це був новий інструмент сусідського співробітництва, який включав транскордонну i регіональну співпрацю задля реалізації цілей зовнішньої політики, економічного і соціального вирівнювання [4; 5].

Реалізація програм сусідства $\epsilon$ одним 3 ефективних способів залучення коштів $С$ С для вирішення проблем соціального й економічного розвитку прикордонних регіонів. Україна брала участь у чотирьох спільних операційних програмах прикордонного співробітництва Європейського інструменту сусідства 2014-2020 рр.: «Польща - Україна - Білорусь», «Угорщина - Словаччина Румунія - Україна», «Румунія - Україна» та «Басейн Чорного моря».

Розподіл бюджету Програми «Польща Україна - Білорусь» за пріоритетами наведено в табл. 1.

\section{Таблиця 1 - Індикативний фінансовий план Програми СІС ТКС ПБУ 2014-2020 рр.}

\begin{tabular}{|l|c|c|c|c|}
\hline \multicolumn{1}{|c|}{ - } & $\begin{array}{c}\text { Фінансування } \\
\mathbf{\epsilon C}(\mathbf{a})\end{array}$ & $\begin{array}{c}\text { Мінімальна сума } \\
\text { співфінансування } \\
\text { бенефіціарів (b) }\end{array}$ & $\begin{array}{c}\text { Частка } \\
\text { співфінан- } \\
\text { сування } \\
\text { (у \%) (c) }\end{array}$ & $\begin{array}{c}\text { Загальна } \\
\text { сума фінан- } \\
\text { сування } \\
\text { (d)= (a)+(b) }\end{array}$ \\
\hline Тематична ціль «Спадщина» & 32272159,47 & 3570024,59 & $11,06 \%$ & 35842184,06 \\
\hline Тематична ціль «Доступність» & 55855660,59 & 6178888,71 & $11,06 \%$ & 62034549,30 \\
\hline Тематична ціль «Безпека» & 44270782,82 & 4897341,42 & $11,06 \%$ & 49168124,24 \\
\hline Тематична ціль «Кордони» & 33099650,72 & 3661563,68 & $11,06 \%$ & 36761214,40 \\
\hline Технічна допомога & 17579930,40 & 0,00 & $0,00 \%$ & 17579930,40 \\
\hline УСьОГО & 183078184,00 & 18307818,40 & $10,00 \%$ & 201386002,40 \\
\hline
\end{tabular}

Джерело: складено за [4] 
Програма «Угорщина - Словаччина Румунія - Україна» 2014-2020 рр. передбачала загальний бюджет 73,9 млн євро, спрямованих на підтримку місцевої культури, історичної спадщини, туризму; збереження природних ресурсів та раціональне використання навколишнього середовища в транскордонній зоні; удосконалення інфраструктури (транспортної, IКТ); підтримку спільних заходів та дій для запобігання природним i антропогенним катастрофам, у разі надзвичайних ситуацій; сприяння поліпшенню людського здоров'я [5].

Програма «Україна - Румунія» 3 11-ма тематичними цілями Європейського інструменту сусідства націлена на чотири тематичні цілі: 1. Підтримка освіти, досліджень, технологічного розвитку та інновацій. 2. Просування місцевої культури й збереження історичної спадщини. 3. Покращення доступу до регіонів, розвиток транспортних i комунікаційних мереж та систем. 4. Спільні виклики у сфері безпеки й захисту [5].

Програма «Басейн Чорного моря» 2014-2020 pp. мала на меті поліпшення добробуту мешканців Чорноморського регіону завдяки стабільному економічному зростанню та захисту навколишнього середовища за допомогою розвитку бізнесу й підприємництва в межах туризму; розширення можливостей транскордонної торгівлі та модернізації прилеглих сільськогосподарських територій; удосконалення системи контролю над забрудненням навколишнього середовища; сприяння обізнаності громади й уживання заходів щодо скорочення річкового та морського сміття. Бюджет програми такий: 39,039 (із фонду Свропейського інструменту сусідства $\mathrm{ENI}+$ Свропейського структурного фонду розвитку ERDF); 10,000 (із Передвступного фонду IPA) [3; 6].

Отримання фінансової допомоги від участі в таких програмах стало важливим джерелом інвестування у сфері транскордонного співробітництва.

Визначення передумов розвитку транскордонного співробітництва базується на аналізі соціально-економічного розвитку регіонів України. Узагальнювальним показ- ником рівня регіонального розвитку є валовий регіональний продукт. Деякі регіони, що входять до складу єврорегіонів, значно відстають за показником валового регіонального продукту на одного жителя, причому серед них не лише ті, що межують із Росією, а й ті, що мають спільний кордон 3 ЄC (Волинська - 34,3; Закарпатська - 25,7; Івано-Франківська - 37,2; Чернівецька 23,4). Прямі іноземні інвестиції - важливий чинник соціально-економічного розвитку регіону. Потрібно відзначити відносно невисокі обсяги прямих іноземних інвестицій на одну особу в низці прикордонних регіонів, які є учасниками транскордонного співробітництва. Зокрема, це стосується Вінницької, Волинської, Закарпатської та Чернівецької областей [6]. Це свідчить про недостатнє використання можливостей транскордонного співробітництва.

Водночас дедалі більшої актуальності набувають питання активізації міжрегіонального співробітництва східних регіонів України 3 регіонами держав - членів СС. Проблемами, що стримують ефективність транскордонного співробітництва в Україні, $\epsilon$ такі [7]:

- диспропорції соціально-економічного розвитку регіонів. У 2019 р. найнижчими в рейтингу були показники соціально-економічного розвитку таких прикордонних регіонів, як Волинська (21-е місце), Сумська (23-е місце), Закарпатська (24-е місце) та Луганська (25-е місце) області;

- низький рівень зайнятості населення регіонів України, у тому числі прикордонних, зокрема у 2018 р. найнижче значення цього показника спостерігалося у Волинській $(55,9 \%)$ та Донецькій $(58,1 \%)$ областях. За період із 2014 по 2019 р. більше ніж на 3 млн осіб зменшилася кількість економічно активного населення України;

- високий рівень безробіття населення в Україні, що веде за собою збільшення потоків трудової міграції за кордон, і більше половини кількості трудових мігрантів становлять мешканці західних регіонів;

- негативний зовнішньоторговельний баланс, низький темп приросту експорту та імпорту товарів і послуг, значне переважання у структурі експорту сировинних 
товарів та товарів із відносно низьким технологічним складником;

- низький рівень міграційного приросту населення;

- незавершеність правового оформлення та демаркації кордону;

- низька пропускна спроможність пунктів пропуску через державний кордон та невідповідний рівень їх облаштування;

- відсутність достатнього обсягу фінансового забезпечення здійснення проєктів та програм транскордонного співробітництва;

- низький рівень використання суб'єктами транскордонного співробітництва форм транскордонного співробітництва; низький рівень активності учасників транскордонного співробітництва щодо реалізації транскордонних проєктів, низька якість проєктного менеджменту на рівні суб'єктів транскордонного співробітництва.

Передумови активізації транскордонного співробітництва [6]:

1) кризові явища в економіці циклічного та нециклічного характеру (повільний перехід до ринкової економіки, висока залежність від імпорту енергоносіїв, низька конкурентоспроможність української продукції, імпортозалежність, низька купівельна спроможність населення). Нагромадження цих кризових явищ спровокувало політичну кризу, а російська агресія нанесла додатковий удар економіці. Усе це створює негативні передумови для розвитку транскордонного співробітництва;

2) розвиток ринкових умов господарювання. Офіційно Україна вважається країною $з$ ринковою економікою, однак результати аналізу соціально-економічних показників свідчать, що в нашій державі ще не створено передумов, які б забезпечували дієвість «невидимої руки ринку»;

3) поглиблення європейської інтеграції виступає одним із пріоритетів зовнішньої політики України;

4) проведення реформ, що $\epsilon$ умовою виконання вимог Угоди про асоціацію між Україною та $\mathrm{CC}$;

5) зміна ролі та функцій територіальних громад унаслідок децентралізації в умовах реалізації адміністративно-територіальної реформи;
6) міграційні процеси, при цьому існують внутрішні переселення, які пов'язані 3 конфліктом на Донбасі, анексією Криму, а також зовнішні міграційні процеси, які зумовлені виїздом населення за кордон на постійні або тимчасові умови проживання.

Стратегії активізації транскордонного співробітництва регіонів повинні розроблятися з урахуванням напрямів і пріоритетів, визначених у загальнодержавних документах (зокрема, у Державній програмі розвитку транскордонного співробітництва на 2021-2027 pp., законах України «Про засади державної регіональної політики», «Про співробітництво територіальних громад», «Про засади внутрішньої і зовнішньої політики», «Про асоціації органів місцевого самоврядування», «Про стимулювання розвитку регіонів», «Про місцеве самоврядування в Україні», «Про місцеві державні адміністрації», «Про державне прогнозування та розроблення програм економічного і соціального розвитку України», «Про добровільне об'єднання територіальних громад»), регіональних стратегіях, а також документах Європейського Союзу, у яких задеклароване питання розвитку регіонів та міст («Свропейська рамкова конвенція про транскордонне співробітництво між територіальними общинами або властями» та додатки до неї, «Європейська хартія прикордонних і транскордонних регіонів», Європейська хартія місцевого самоврядування, Хартія Конгресу місцевих і регіональних органів влади Свропи, Декларація Асамблеї європейських регіонів щодо регіоналізму в Європі, Свропейська хартія регіонального просторового планування тощо) [1].

Протягом 2016-2020 pp. забезпечувалося виконання Державної програми розвитку транскордонного співробітництва на 2016-2020 рр. шляхом здійснення заходів та реалізації проєктів транскордонного співробітництва, спрямованих на розвиток транскордонного співробітництва та формування позитивного інвестиційного іміджу України. Разом із тим у зв'язку 3 недостатнім обсягом фінансування зазначених заходів та проєктів із державного бюджету залишилися не розв'язаними проблеми розвитку прикордонної транспорт- 
ної інфраструктури, охорони і відновлення екосистем регіонів, низької інституційної спроможності суб'єктів та учасників транскордонного співробітництва. У Державній програмі розвитку транскордонного співробітництва на 2021-2027 рр. передбачено такі пріоритетні напрями [7]:

- реалізація в Україні Стратегії Свропейського Союзу для Дунайського регіону та Дунайської транснаціональної програми;

- реалізація проєктів та програм, що фінансуються за рахунок міжнародної технічної допомоги, а також програм прикордонного співробітництва у рамках Свропейського територіального співробітництва на 2021-2027 pр. в рамках фінансового інструменту «Сусідство, розвиток і міжнародне співробітництво» (NDICI);

-забезпечення розвитку прикордонної інфраструктури гірських Карпат;

- забезпечення розвитку інституційної спроможності суб'єктів та учасників транскордонного співробітництва (у тому числі асоціацій органів місцевого самоврядування, агенцій регіонального розвитку, громадських організацій, європейських об'єднань територіального співробітництва та інших форм транскордонного співробітництва).

3 огляду на потребу створення сприятливого середовища для регіонального розвитку, можна виділити такі стратегічні напрями активізації транскордонного співробітництва [1]:

1. Адаптація регіональної політики України до регіональної політики Свропейського Союзу в контексті реалізації Угоди про асоціацію з $\mathrm{CC.}$

2. Координація транскордонного співробітництва на державному, регіональному, місцевому та громадському рівнях.

3. Децентралізація державного управління, розвиток територіальних громад.

4. Конвергенція, зменшення диспропорцій регіонального розвитку.

5. Розвиток транскордонної кооперації, налагодження партнерських відносин, що здійснюються за допомогою спільних програм і проєктів, управління якими дає змогу отримати транскордонний ефект та створити умови для поліпшення якості життя населення в регіонах.
6. Інвестиційне забезпечення розвитку транскордонного співробітництва.

7. Запровадження нових форм транскордонного співробітництва, таких як транскордонне партнерство, транскордонні кластери, транскордонні проєкти, що в сучасних умовах імплементації положень Угоди з Свропейським Союзом дасть змогу активізувати канали транскордонної співпраці й підвищити транскордонний ефект. Серед перспективних форм сучасні фахівці виокремлюють євроокруг - об'єднання, що утворюється завдяки двостороннім та багатостороннім угодам транскордонного співробітництва на території населених пунктів (міст, селищ) або міських агломерацій, які локалізовані на транскордонній території двох або більше держав. Перспективним напрямом є створення міжнародних консорціумів університетів та науково-дослідних установ - форми транскордонного співробітництва між університетами, науководослідними установами України та країни (країн) ЄC [8].

8. Моніторинг розвитку транскордонного співробітництва.

9. Реалізація стратегічного напряму «Поглиблення євроінтеграційних процесів» передбачає запровадження програм, спрямованих на входження України в європейський інтеграційний простір і визнання іï європейськими партнерами, що потребує координації зусиль із розвитку співпраці 3 країнами СС. У зв'язку з розширенням та поглибленням економічного співробітництва країн - членів СС та України прикордонні регіони повинні стати зонами контакту національних господарств, а їхні міжнародні проєкти - точками росту економіки та соціуму областей [1].

Поширення COVID-19 вплинуло на модель поведінки суспільства 3 акцентуванням уваги на ізоляції та діджиталізації та внесло значні зміни в роботу державних та місцевих органів влади. Реалізація взаємовигідних програм та проєктів у майбутньому сприятиме розвитку соціально-економічного стану міст та регіонів. Пандемія суттєво вплинула на електронну комерцію, надавши їй вагому перевагу над офлайн-торгівлею. Пандемія показала, що електронна 
торгівля може бути важливим інструментом, підтримувати малий бізнес, бути економічним двигуном як для внутрішнього зростання, так і для транскордонної торгівлі [2].

Необхідно змінити існуючий підхід до сприйняття транскордонного співробітництва виключно як джерела залучення коштів на користь нового підходу, що передбачатиме сприйняття інструментів транскордонного співробітництва у контексті взаємно скоординованого співробітництва регіонів України та $Є С$ щодо активізації розвитку транскордонних територій та встановлення європейських стандартів в управлінні, господарській сфері, міжкультурній взаємодії [8].

Висновки. Процеси поглиблення європейської інтеграції виступають чинни- ком залучення інвестицій, розширення регіональних ринків, налагодження транскордонних зв'язків. Транскордонне співробітництво в сучасних умовах набуває різноманітних форм. Серед них найбільш перспективні ті, що передбачають надання більшої самостійності органам регіональної й місцевої влади в прийнятті рішень євроінтеграційного характеру та використанні можливостей активізації транскордонного співробітництва. Тому доцільно в подальшому досліджувати нові можливості транскордонного співробітництва внаслідок децентралізації та адаптації механізму реалізації транскордонної співпраці до умов українських прикордонних регіонів.

\section{Список використаних джерел:}

1. Корнелюк О.А. Стратегічні напрями активізації транскордонного співробітництва міських поселень в умовах євроінтеграції. Інтелект XXI. 2019. № 3. C. 9-15. URL: http://www.intellect21.nuft.org.ua/journal/2019/2019_3/1.pdf.

2. Корнелюк О.А., Завадська Ю.І., Чапко Р.В. Форми реалізації транскордонного співробітництва в Свропейському Союзі. Інноваційна економіка. 2021. № 3-4. C. 12-18. URL: http://inneco.org/ index.php/innecoua/article/view/763.

3. Офіційний сайт Програми транскордонного співробітництва ЄІСП «Басейн Чорного моря 2014-2020». URL: http://blacksea-cbc.net/black-sea-basin-2014-2020/.

4. Офіційний сайт Програми транскордонного співробітництва ЄІСП «Польща - Білорусь Україна 2014-2020». URL: https://www.pbu2020.eu/ua.

5. Офіційний сайт Програми транскордонного співробітництва ЄІСП «Угорщина - Словаччина - Румунія - Україна 2014-2020». URL: http://www.huskroua-cbc.net/ua/.

6. Павліха Н.В., Корнелюк О.А. Активізація транскордонного співробітництва міських поселень : монографія. Луцьк : Вежа-Друк, 2019. 212 c. URL: https://evnuir.vnu.edu.ua/handle/123456789/18484.

7. Постанова Кабінету Міністрів України «Про затвердження Державної програми розвитку транскордонного співробітництва на 2021-2027 роки» від 14 квітня 2021 p. URL: https://zakon.rada.gov.ua/laws/show/408-2021-\%D0\%BF\#Text.

8. Химинець В.В., Головка А.А., Мірус О.І. Транскордонне співробітництво як інструмент місцевого та регіонального розвитку : аналітична доповідь. Київ : НICД, 2021. 47 с. URL: https://niss.gov.ua/sites/default/files/2021-09/analytrep_13_2021.pdf.

\section{References:}

1. Korneliuk O.A. (2019) Stratehichni napriamy aktyvizatsii transkordonnoho spivrobitnytstva miskykh poselen $\mathrm{v}$ umovakh yevrointehratsii [Strategic directions of intensification of cross-border cooperation of urban settlements in the conditions of European integration]. Intelekt XXI, no. 3, pp. 9-15. Available at: http://www.intellect21.nuft.org.ua/journal/2019/2019_3/1.pdf.

2. Korneliuk O.A., Zavadska Yu.I., Chapko R.V. (2021) Formy realizatsii transkordonnoho spivrobitnytstva $\mathrm{v}$ Yevropeiskomu Soiuzi [Forms of implementation of cross-border cooperation in the European Union]. Naukovyi zhurnal «Innovatsiina ekonomika» [Onlainovyi resurs], no. 3-4, pp. 12-18. Available at: http://inneco.org/index.php/innecoua/article/view/763.

3. Ofitsiinyi sait Prohramy transkordonnoho spivrobitnytstva YeISP Basein Chornoho moria 2014-2020 [Official website of the ENPI Cross-Border Cooperation Program Black Sea Basin 2014-2020]. Available at: http://blacksea-cbc.net/black-sea-basin-2014-2020/. 
4. Ofitsiinyi sait Prohramy transkordonnoho spivrobitnytstva YeISP Polshcha-Bilorus-Ukraina 2014-2020 [Official website of the ENPI Cross-Border Cooperation Program Poland-Belarus-Ukraine 2014-2020]. Available at: https://www.pbu2020.eu/ua.

5. Ofitsiinyi sait Prohramy transkordonnoho spivrobitnytstva YeISP Uhorshchyna-Slovachchyna-Rumuniia-Ukraina 2014-2020 [Official site of the ENPI Hungary-Slovakia-Romania-Ukraine Cross-Border Cooperation Program 2014-2020]. Available at: http://www.huskroua-cbc.net/ua/.

6. Pavlikha N.V., Korneliuk O.A. (2019) Aktyvizatsiia transkordonnoho spivrobitnytstva miskykh poselen : monohrafiia [Activation of cross-border cooperation of urban settlements: monograph] / Skhidnoievropeiskyi natsionalnyi universytet imeni Lesi Ukrainky. Lutsk: Vezha-Druk, 212 p. Available at: https://evnuir.vnu.edu.ua/handle/123456789/18484.

7. Postanova Kabinetu Ministriv Ukrainy «Pro zatverdzhennia Derzhavnoi prohramy rozvytku transkordonnoho spivrobitnytstva na 2021-2027 roky» [Resolution of the Cabinet of Ministers of Ukraine "On approval of the State program for the development of cross-border cooperation for 2021-2027"] vid 14 kvitnia 2021 r. Available at: https://zakon.rada.gov.ua/laws/show/408-2021-\%D0\%BF\#Text.

8. Khymynets V.V., Holovka A.A., Mirus O.I. (2021) Transkordonne spivrobitnytstvo yak instrument mistsevoho ta rehionalnoho rozvytku [Cross-border cooperation as a tool for local and regional development]: analit. dop. Kyiv: NISD, 47 p. Available at: https://niss.gov.ua/sites/default/files/2021-09/analytrep_13_2021.pdf.

Korneliuk Olga, Matiushok Victoria Lesya Ukrainka Volyn National University

\section{CROSS-BORDER COOPERATION OF THE REGIONS OF UKRAINE IN THE CONTEXT OF INTERNATIONAL ECONOMIC INTEGRATION}

The participation of the regions of Ukraine in cross-border cooperation contributes to the acceleration of Ukraine's European integration processes and is an effective tool for achieving the Sustainable Development Goals. The study uses generally accepted methods in economics: a monographic, theoretical, and comparative analysis; synthesis, system-structural, abstract and logical, statistical groupings - to determine and analyse the forms of cross-border cooperation. An important role in the development of cross-border cooperation belongs to the implementation of Neighborhood Programs. It is one of the ways to attract funds from the European Union for solving the problems of social and economic development of border regions. The analysis of the socio-economic development of the regions of Ukraine shows that they do not use the potential of cross-border cooperation, in connection with which there is a need to intensify cross-border cooperation. Prerequisites for intensifying cross-border cooperation are: crises in the economy, the development of market conditions, deepening European integration, reforms, changing the role and functions of urban settlements, migration. A necessary condition for achieving the sustainable spatial development of the regions is the development of an effective strategy taking into account: adaptation of Ukraine's regional policy to the regional policy of the European Union; coordination of cross-border cooperation at the state, regional, local and public levels; decentralization of public administration and development of territorial communities; convergence, reduction of regional development disparities; development of cross-border partnerships; investment support for the development of cross-border cooperation; introduction of new forms of cross-border cooperation; deepening of European integration processes, etc. The spread of the pandemic has also created a need to improve the existing cooperation mechanism. The results of the conducted study can be used in the educational process, in particular, in the training of specialists in project management, as well as in the implementation of practical activities of public authorities and local governments of urban settlements, cities, and regions that are cross-border regions.

Key words: cross-border cooperation, strategy of cross-border cooperation, European integration, activation of cross-border cooperation, socio-economic development of the region, cross-border program, cross-border project.

JEL classification: F02, F15, F21, F35 